\title{
Influence of Industrial Work Practice, Competence Examination Test and Learning Motivation on Student Competence
}

\author{
Tomi Rachmad Santoso* \\ Master of Management Study Program Mandala Jember College of Economics East Java - Indonesia
}

\author{
A R T I C L E I N F O \\ Article history: \\ Received 19 February 2019 \\ Received in revised form \\ 16 March 2019 \\ Accepted 15 April 2019 \\ Available online 26 May \\ 2019 \\ Kata Kunci: \\ praktek kerja industri,uji \\ kompetensi keahlian,motivasi \\ belajar, kompetensi siswa \\ Keywords: \\ industrial work practices, \\ competency testing skills, \\ learning motivation, student \\ competence
}

\section{A B S T R A K}

Penelitian ini bertujuan untuk mengetahui: (1) Pengaruh Praktek kerja industri, Uji kompentensi keahlian dan motivasi belajar secara parsial dan simultan berpengaruh terhadap kompetensi siswa, (2) Variabel yang paling dominan berpengaruh terhadap kompetensi siswa.Pada penelitian ini menggunakan pendekatan kuantitatif dengan metode studi kasus. Sampel yang digunakan adalah siswa kelas XII Jurusan Teknik Kendaraan Ringan di SMKN Ihya' Ulumudin Kabupaten Banyuwangi pada Tahun Pelajaran 2015-2016 dengan jumlah populasi sebanyak 84 siswa.Teknik pengumpulan data menggunakan metode angket dan dokumentasi.Teknik analisis data menggunakan uji asumsi klasik, uji normalitas, uji heteroskedastisitas dan uji multikolinieritas. Sedangkan pengujian hipotesis menggunakan analisis regresi berganda,uji $F$ statistik dan uji $T$. Hasil penelitian menunjukkan bahwa (1) Varibel bebas secara parsial berpengaruh signifikan terhadap variabel terikat. Simpulan dari penelitian ini adalah Praktek kerja industri, uji kompetensi keahlian dan motivasi belajar harus terus dilakukan dan ditingkatkan kualitasnya dengan sungguhsungguh dan konsisten untuk meningkatkan kompetensi siswa.

\section{A B S T R A C T}

This research to find out: (1) Effect of industrial work practices, Test of competence and learning motivation partially and simultaneously affect for student competencies, (2) The most dominant variable influences student competency. In this research using a quantitative approach with study methods case. The sample was class XII Teknik Kendaraan Ringan vocational high scholl of SMKN Ihya' Ulumudin Singojuruh - Banyuwangi in Academic Year 2015 - 2016 with the population of 84 students. Data collection techniques used questionnaire and documentation methods. Data analysis techniques used classical assumption test, normality test, heteroscedasticity test and multicollinearity test. While testing hypotheses used multiple regression analysis, statistical $\mathrm{F}$ test and $T$ test. The results showed that (1) partially independent variables have a significant effect on the dependent variable. The conclusion of this research industrial work practices, skill competency tests and learning motivation must continue to be carried out and improve their quality seriously and consistently to improve student competence.

\footnotetext{
* Corresponding author.

E-mail addresses: tommy1person@gmail.com (Tomi Rachmad Santoso)
} 


\section{Pendahuluan}

Seiring perkembangan industri di Indonesia, kebutuhan industri terhadap tenaga kerja cukup besar. Menurut data badan pusat statistik, jumlah perusahan industri di Indonesia berdasarkan skala usaha besar sedang di Indonesia pada tahun 2013 mencapai 23.941 industri. Banyaknya jumlah industri ini disebabkan kebutuhan masyarakat Indonesia yang semakin meningkat. Peningkatan kuantitas industri akan meningkatkan tingkat perekonomian Indonesia serta kebutuhan akan tenaga kerja. Oleh karena itu, untuk memenuhi kebutuhan akan tenaga kerja tersebut dibutuhkan suatu program persiapan calon tenaga kerja yang bisa meningkatkan kompetensi untuk mendukung efisiensi dan produktifitas, serta meningkatkan daya saing (http://www.kemenperin.go.id/artikel/5592/kebutuhan-tenaga-kerja-terusmeningkat).

Dunia industri selalu menerapkan standar kompetensi untuk calon tenaga kerja yang akan bekerja. Standar kompetensi bertujuan untuk menjaga kualitas tenaga kerja dalam bekerja, agar bisa bekerja dengan produktif. Apalagi industri selalu berorientasi pada profit. Semua faktor yang berkaitan dengan keberlangsungan produksi akan selalu dikondisikan dalam keadaan yang terbaik. Oleh karena itu, standar kompetensi tenaga kerja merupakan salah satu faktor yang akan menjaga keberlangsungan produksi agar berjalan maksimal. Untuk mendapatkan tenaga kerja yang sesuai dengan standar kompetensi industri, maka dalam merekrut kebutuhan tenaga kerja dilakukan dengan teliti dan melalui seleksi yang ketat. Salah satu calon tenaga kerja untuk memenuhi kebutuhan tersebut adalah berasal dari lulusan SMK.

Sekolah Menengah Kejuruan (SMK) adalah sekolah yang mempersiapkan peserta didiknya untuk siap bekerja, baik secara mandiri maupun dalam sebuah kelompok sesuai dengan bidang keahlian masingmasing. SMK didirikan untuk mengantisipasi kebutuhan tenaga kerja yang berkualitas dan memenuhi standar kompetensi industri. Pendidikan kejuruan telah terbukti mempunyai peran yang besar dalam pembangunan industri, seperti yang ada di Negara Jerman. Gatot Hari Priyowiryanto dalam Soegiono (2003:12) menyatakan bahwa jerman menjadi Negara industri yang tangguh karena didukung tenaga kerja yang terampil lulusan sekolah kejuruan $80 \%$ dari total sekolah menengah di jerman adalah sekolah kejuruan.

Tujuan pendidikan SMK yang tertuang dalam peraturan pemerintah No 29 tahun 1990, pasal 3 ayat 2 (http://jabar.kemenag.go.id/file/file/produk hukum/wnmd1401767965.pdf) secara mendasar adalah untuk menyiapkan siswa memasuki dunia kerja, serta untuk mengembankan sikap profesionalisme. Lulusan SMK seharusnya memiliki keahlian sebagai modal untuk memasuki dunia industri. Kesesuaian kurikulum dan pembelajaran di SMK akhirnya harus mengacu pada kebutuhan industri. Komunikasi harus dibangun antara SMK dengan industri agar menjadi jembatan yang bisa menghubungkan dua lembaga yang saling memiliki kepentingan ini. Prosser dan Allen dalam Soenarto (2003:17) menjelaskan bahwa pendidikan kejuruan yang efektif hanya akan diberikan jika tugas latihan dilakukan dengan cara, alat dan mesin yang sama seperti yang diterapkan di tempat kerja. Oleh karena itu, upaya untuk menghasilkan kompetensi siswa sesuai kebutuhan industri bisa diperoleh dengan menerapkan pendidikan dan pelatihan secara langsung di industri. Salah satu program SMK yang dilaksanakan untuk meningkatkan standar kompetensi siswa SMK agar sesuai kebutuhan industri adalah program praktek kerja industri (Prakerin) yang ada di SMK Negeri Ihya Ulumudin Singojuruh Kabupaten Banyuwangi dalam pelaksanaannya dilakukan dalam 3 Bulan.

Keputusan Menteri Pendidikan Dan Kebudayaan Republik Indonesia nomor 323/U/1997 (http://jodenmot.wordpress.com/2013/03/07/pendidikansistemganda-di-smk) menjelaskan bahwa prakerin merupakan program pendidikan sistem ganda yang terpadu agar kegiatan praktik belajar bukan hanya dilaksanakan di sekolah, tetapi juga di dunia industri. Tujuannya adalah untuk memberikan pengalaman kepada siswa tentang bekerja di industri dan menjadi bekal agar siswa handal mampu bersaing di dunia kerja yang akan dihadapi setelah kelulusan. Prakerin merupakan kegiatan pendidikan, pelatihan dan pembelajaran yang dilaksanakan di dunia industri yang sesuai dengan bidang keahlian masing-masing SMK bertanggung jawab penuh dalam mendidik siswanya serta berkewajiban untuk menjaga keberlangsungan program prakerin agar berjalan dengan baik. Selain itu, tentunya sekolah juga memiliki harapan dan tujuan agar output dari program prakerin ini bisa meningkatkan kompetensi siswa sesuai yang diinginkan sekolah.

Kompetensi siswa perlu di uji dan dievaluasi dengan Uji Kompetensi Keahlian, dimana alur kegiatan Uji kompetensi dilakukan setelah siswa tersebut melaksanakan program prakerin di dunia industri, Uji Kompetensi Keahlian adalah bagian dari intervensi Pemerintah dalam menjamin mutu pendidikan pada satuan pendidikan Sekolah Menengah Kejuruan. Pelaksanaannya bertujuan untuk mengukur pencapaian kompetensi siswa pada level tertentu. Uji Kompetensi terdiri dari Ujian Praktik Kejuruan yang umumnya diselenggarakan sebelum pelaksanaan Ujian Nasional dan Ujian Teori Kejuruan yang merupakan bagian dari rangkaian pelaksanaan Ujian Nasional. Ujian Praktik Kejuruan dapat 
dilaksanakan menggunakan standar yang ditetapkan oleh industri, Lembaga Sertifikasi Profesi dan perangkat uji yang dikeluarkan oleh Kementerian Pendidikan dan Kebudayaan di Tempat-tempat Uji Kompetensi. Satuan pendidikan yang menyelenggarakan Uji Kompetensi harus dinyatakan layak sebagai tempat Uji Kompetensi oleh koordinator Ujian Nasional Tingkat Provinsi atau Lembaga Sertifikasi Profesi

Pendidikan kejuruan bertujuan untuk menghasilkan manusia yang produktif, yaknimanusia kerja, bukan manusia beban keluarga,masyarakat, dan bangsanya (Soenaryo, et al. 2002: 17). Hal ini sebagaimana yang dikatakan oleh Finch \& Crunkilton (1999: 250) bahwa sekolah harus bisa menjadi jembatan bagi peserta didik untuk memasuki dunia kerja. Pendidikan kejuruan memiliki beberapa manfaat yaitu: a. Bagi siswa: 1) peningkatan kualitas diri, 2) peningkatan penghasilan, 3) penyiapan bekal pendidikan lebih lanjut, 4) penyiapan diri agar berguna bagi masyarakat dan bangsa, b. Bagi dunia kerja: 1) dapat memperoleh tenaga kerja berkualitas tinggi, 2) dapat meringankan biaya usaha, 3) dapat membantu memajukan dan mengembangkan usaha, dan c. Bagi masyarakat: 1) dapat meningkatkan kesejahteraan masyarakat, 2) dapat meningkatkan produktivitas nasional sehingga dapat meningkatkan penghasilan Negara, 3) dapat mengurangi pengangguran

Selain Praktek Kerja Industri dan Uji Kompetensi Keahlian, Motivasi belajar juga sangat berpengaruh terhadap Kompetensi siswa. Motivasi adalah sesuatu yang dibutuhkan untuk melakukan aktivitas. Dalam artikel Siti Sumarni (2005), motivasi secara harafiah yaitu sebagai dorongan yang timbul pada diri seseorang secara sadar atau tidak sadar, untuk melakukan suatu tindakan dengan tujuan tertentu. Sedangkan secara psikologi, berarti usaha yang dapat menyebabkan seseorang atau kelompok orang tergerak melakukan sesuatu karena ingin mencapai tujuan yang dikehendakinya, atau mendapat kepuasan dengan perbuatannya. (KBBI, 2001:756). pengertian di atas bahwa pada prinsipnya, belajar adalah perubahan dari diri seseorang. Dari uraian tersebut dapat disimpulkan bahwa pengertian motivasi belajar adalah keseluruhan daya penggerak baik dari dalam diri maupun dari luar siswa (dengan menciptakan serangkaian usaha untuk menyediakan kondisi-kondisi tertentu) yang menjamin kelangsungan dan memberikan arah pada kegiatan belajar.

Dengan melihat program sekolah pada SMK Negeri Ihya Ulumudin Singojuruh yaitu Program Praktek Kerja Industri, Uji Kompetensi Keahlian serta Pemberian Motivasi Belajar yang berkelanjutan terhadap siswa, Diharapkan mampu dalam meningkatkan Kompetensi di bidang Kejuruan Teknik Kendaraan Ringan.

Dari uraian latar belakang tersebut, maka penulis mengambil judul "Pengaruh Praktek Kerja Industri, Uji Kompetensi Keahlian Dan Motivasi Belajar Terhadap Kompetensi Siswa Di SMK Negeri Ihya' Ulumudin Singojuruh Kabupaten Banyuwangi".

\section{Metode}

Dalam penelitian ini menggunakan pendekatan kuantitatif artinya semua informasi atau data diwujudkan dengan angka dan analisisnya menggunakan analisis statistik IBM SPSS Statistik Versi 23. Dalam penelitian ini selain menggunakan pendekatan kuantitatif, penelitian juga berbentuk kausalitas. Menurut ferdinan (2006) penelitian kausalitas adalah penelitian yang ingin mencari kejelasan dan bentuk hubungan sebab-akibat ( cause-effect ) antar beberapa konsep dan beberapa variable atau beberapa strategi yang dikembangkan dalam manajemen. Berdasarkan permasalahan pada penelitian ini, maka desain penelitian ini adalah penelitian kausal komparatif. Hal ini dikarenakan dalam penelitian ini bertujuan mengetahui sebab akibat dan pengaruh praktek kerja industri, uji kompetensi keahlian dan motivasi belajar terhadap kompetensi siswa Kelas XII Jurusan Teknik Kendaraan Ringan di SMKN Ihya' Ulumudin Kecamatan Singojuruh Kabupaten Banyuwangi.

Penelitian ini jugan merupakan penelitian ex post facto yaitu penelitian yang dilakukan atas peristiwa yang telah terjadi dan untuk mengungkap data yang ada atau menggambarkan variabel-variabel penelitian tanpa memberikan perlakuan atau manipulasi terhadap subyek yang diteliti.

Untuk mengungkap data tentang pengaruh praktek kerja industri, uji kompetensi keahlian dan motivasi belajar dan terhadap kompetensi siswa, dalam penelitian ini metode pengumpulan data menggunakan angket atau kuesioner dan dokumentasi. Dalam penilitian ini seluruh populasi dijadikan sampel penelitian yaitu sebanyak 84 responden. 


\section{Hasil dan pembahasan} berikut ini.

Hasil perhitungan analisis regresi linier berganda dalam penelitian ini Ditunjukkan dalam Tabel 1

Tabel 1. eHasil Analisis Regresi Linier Berganda

\begin{tabular}{lllll}
\hline \multirow{2}{*}{ No. $\quad$ Variabel Bebas } & \multicolumn{3}{l}{ Koefisien } & \multicolumn{2}{l}{ Penyajian hipotesis } & \multirow{2}{*}{ Sign. } \\
\hline $1 . \quad$ Prakerin $\left(\mathrm{X}_{1}\right)$ & regresi & t-hitung & t-tabel & \\
\hline 2. $\quad$ UKK $\left(\mathrm{X}_{2}\right)$ & 0,211 & 3,142 & 1,667 & 0,002 \\
$3 . \quad$ Motivasi Belajar $\left(\mathrm{X}_{3}\right)$ & 0,273 & 3,930 & & 0,000 \\
\hline Konstanta & 0,402 & 3,985 & \\
$\mathrm{R}^{2}$ & $=5,901$ & & \\
Adjusted $\mathrm{R}^{2}$ & $=0,000$ \\
F-hitung & $=0,698$ & & \\
F-tabel & $(5 \% ; 3,10)$ & $=65,038$ & & \\
Signifikansi & $=3,710$ & & \\
\hline
\end{tabular}

Sumber : Lampiran, data diolah

Berdasarkan hasil analisis regresi linier berganda diperoleh persamaan regresi sebagai berikut :

Dari persamaan regresi linier berganda di atas dapat dilihat pengaruh dari variabel-variabel independen (Prakerin, UKK dan Motivasi Belajar) terhadap variabel dependen (Kompetensi Siswa), sedangkan makna dari persamaan regresi linier berganda di atas dapat dijelaskan sebagai berikut :

a. Konstanta persamaan regresi $\left(b_{0}\right)$ bernilai positif sebesar 5,901 , berarti bahwa jika tidak terdapat nilai-nilai pada variabel independen atau variabel-variabel bebas sama dengan nol, maka produktivitas kerja adalah sebesar 5,901.

b. Koefisien regresi variabel Prakerin $\left(b_{1}\right)$ bernilai positif sebesar 0,211 berarti bahwa setiap pelaksanaan prakerin akan menimbulkan peningkatan kompetensi siswa sebesar 0,211 satuan dengan asumsi variabel-variabel bebas lainnya konstan.

c. Koefisien regresi variabel UKK $\left(b_{2}\right)$ bernilai positif sebesar 0,273 , berarti bahwa setiap Pelaksanaan UKK, akan menimbulkan peningkatan Kompetensi Siswa sebesar 0,273 satuan dengan asumsi variabel-variabel bebas lainnya konstan.

d. Koefisien regresi variabel Motivasi Belajar $\left(b_{3}\right)$ bernilai positif sebesar 0,402 berarti bahwa setiap Pemberian Motivasi akan menimbulkan peningkatan Kompetensi Siswa sebesar 0,402 satuan dengan asumsi variabel-variabel bebas lainnya konstan.

Uji t dilakukan untuk mengetahui pengaruh variabel independen terhadap variabel dependen secara parsial. Pada pengujian ini membandingkan antara t-hitung dengan t-tabel hasil dari pengujian terhadap masing-masing variabel independen (Praktek Kerja industri, Uji kompetensi keahlian dan Motivasi Belajar) terhadap variabel dependen (Kompetensi Siswa).

Tabel 2. Hasil Uji t

\begin{tabular}{llll}
\hline Variabel & t-hitung & t-tabel & Sig. \\
\hline Prakerin $\left(\mathrm{X}_{1}\right)$ & 3,142 & 1,667 & 0,002 \\
UKK $\left(\mathrm{X}_{2}\right)$ & 3,930 & & 0,000 \\
Motivasi Belajar $\left(\mathrm{X}_{3}\right)$ & 3,985 & & 0,000 \\
\hline
\end{tabular}

Sumber : Lampiran, data diolah

Berdasarkan langkah-langkah uji t dan tabel di atas, maka pengujian hipotesis untuk masingmasing variabel independen Prakerin, UKK dan Motivasi Belajar terhadap Kompetensi Siswa adalah sebagai berikut:

\section{Variabel PRAKERIN $\left(\mathrm{X}_{1}\right)$}

Berdasarkan Tabel di atas diketahui nilai t-hitung variabel gaji adalah sebesar 3,142 dengan nilai probabilitas sebesar 0,002, sedangkan nilai t-tabel adalah sebesar 1,667 (Lampiran ), sehingga t-hitung > t-tabel $(3,142>1,667)$. Hal ini menunjukkan bahwa variabel Prakerin secara parsial mempunyai pengaruh yang signifikan terhadap Kompetensi Siswa. 
Variabel Uji Kompetensi Keahlian $\left(\mathrm{X}_{2}\right)$

Berdasarkan tabel di atas diketahui nilai t-hitung variabel UKK adalah sebesar 3,930 dengan nilai probabilitas sebesar 0,000 , sedangkan nilai t-tabel adalah sebesar 1,667 sehingga t-hitung $>t$-tabel $(3,930$ $>$ 1,667). Hal ini menunjukkan bahwa variabel Uji Kompetensi Keahlian secara parsial mempunyai pengaruh yang signifikan terhadap Kompetensi Siswa.

Variabel Motivasi Belajar $\left(\mathrm{X}_{3}\right)$

Berdasarkan tabel di atas diketahui nilai t-hitung variabel Motivasi Belajar adalah sebesar 3,985 dengan nilai probabilitas sebesar 0,000, sedangkan nilai t-tabel adalah sebesar 1,667 sehingga t-hitung > t-tabel $(3,985>1,667)$. Hal ini menunjukkan bahwa variabel Motivasi Belajar secara parsial mempunyai pengaruh yang signifikan terhadap Kompetensi Siswa.

Pada penelitian ini terdapat variabel bebas (praktek kerja industri,variable uji kompetensi keahlian dan variabel motivasi belajar) dan variabel terikat yaitu variabel kompetensi siswa. Pada masing-masing variabel bebas memiliki pengaruh, baik secara parsial maupun secara simultan terhadap kompetensi siswa. Hal ini berarti kegiatan praktek kerja industri yang sudah ditetapkan salah satunya melalui kepmen pendidikan dan kebudayaan No.323/U/1997 tentang penyelenggaraan PSG/Prakerin SMK dan dilakukan siswa di sekolah harus terus dilakukan dan ditingkatkan kualitas pelaksanaannya agar menghasilkan kompetensi siswa yang dibutuhkan Dunia Usaha/Industri. Saat ini penerapan Praktek kerja industri dilaksanakan dalam waktu 3 bulan, hal ini menyebabkan kurangnya penyerapan ilmu pada saat pelaksanaan prakerin pada dunia usaha/industri,serta masih terdapat beberapa siswa yang hanya sekedar melakukan kegiatannya tetapi tidak memahami maksudnya. Hal ini dapat terjadi dikarenakan banyak siswa yang belum memahami manfaat dalam melaksanakan kegiatan praktek kerja industri. Tentunya pihak sekolah harus terus memberikan informasi kepada siswa tentang pentingnya kegiatan tersebut, karena dengan adanya kegiatan praktek kerja industri memberikan dan sekaligus mengajarkan kepada anak didik bagaimana kehidupan di dunia kerja. disamping ajang uji coba ilmu yang ia pelajari. melalui prakerin siswa diharapkan mampu memahami tentang bagaimana tata dan aturan di dunia industri/usaha, sehingga ketika ia nantinya tamat ia sudah benar-benar siap bekerja baik secara keilmuan maupun secara kejiwaan dan mental

Dari hasil penelitian, uji kompetensi keahlian memiliki pengaruh besar kedua setelah kegiatan motivasi belajar. Dari hasil tersebut uji kompetensi siswa tergolong kurang baik, masih banyak siswa yang tidak mempersiapkan diri dalam melaksanakan uji kompetensi keahlian, hal ini dibuktikan dengan adanya siswa masih bingung dan mendapatkan hasil yang kurang maksimal dalam pelaksanaan uji kompetensi keahlian. Tentunya sekolah melalui guru bidang produktif lebih intensif dalam memantau dan memperhatikan perkembangan psikomotorik siswa, selain itu Guru bimbingan dan konseling dapat memberikan bimbingan agar siswa siap dalam menghadapi uji kompetensi siswa dan mendapatkan hasil maksimal

Motivasi belajar memiliki pengaruh terbesar dalam kompetensi siswa. Dalam penelitian ini dapat diketahui bahwa dengan memberikan motivasi belajar siswa secara berkelanjutan kepada siswa keberhasilan dalam kelulusan dan kompetensi siswa dapat tercapai. Hal ini dapat menjadikan tolak ukur kelulusan serta meraih cita-cita masa depan siswa, disamping itu guru harus berperan aktif membangkitkan semangat dan motivasi kepada siswa,hal ini bisa dilakukan dengan cara menggunakan banyak variasi model pembelajaran sehingga tidak jenuh dalam mengikuti proses belajar baik secara teori maupun kegiatan praktikum di sekolah. Pemberian penghargaan kepada siswa yang berprestasi dapat juga dilakukan untuk meningkatkan semangat dan kompetensi siswa.

\section{Simpulan dan saran}

Berdasarkan hasil penelitian,analisa statistik dan pembahasan tentang Pengaruh praktek kerja industri, Uji Kompetensi keahlian dan motivasi belajar terhadap kompetensi siswa studi empirik di SMK Negeri Ihya Ulumudin Singojuruh Kabupaten Banyuwangi, sebagai berikut: 1) Praktek Kerja Industri, Uji Kompetensi Keahlian dan Motivasi Belajar secara parsial berpengaruh terhadap kompetensi siswa di SMK Negeri Ihya' Ulumudin Singojuruh Kabupaten Banyuwangi, dan 2) Praktek Kerja Industri, Uji Kompetensi Keahlian dan Motivasi Belajar secara simultan berpengaruh terhadap kompetensi siswa di SMK Negeri Ihya' Ulumudin Singojuruh Kabupaten Banyuwangi.

Dari ketiga variabel praktek kerja industry, Uji kompetensi keahlian dan motivasi belajar variabel yang paling dominan terhadap kompetensi siswa di SMK Negeri Ihya' Ulumudin Singojuruh Kabupaten Banyuwangi adalah Motivasi Belajar. 


\section{Daftar Rujukan}

Anni, Catharina Tri, dkk. 2006. Psikologi Belajar. Semarang: Universitas Negeri Semarang Press

Arikunto, Suharsimi, (2004). Prosedur Penelitian Suatu Praktek. Jakarta : Rajawali Press

Arikunto, Suharsimi, (2006). Dasar-dasar Supervisi. Jakarta : Rineka Cipta

Arikunto, Suharsimi. 2009. Dasar-Dasar Evaluasi Pendidikan (Edisi Revisi) Cetakan 9.Jakarta: Bumi Aksara

Arikunto, Suharsimi. 2010. Prosedur Penelitian Suatu Pendekatan Praktik. Jakarta: Rineka Cipta

Arikunto, Suharsimi. (2012). Prosedur Penelitian. Jakarta: Rineka Cipta

BSNP. (2016). Pedoman penyelenggaraan uji kompetensi keahlian (ukk) smk tahun pelajaran 2016/2017. Jakarta: Direktorat Pembinaan Sekolah Menengah Kejuruan.

Dr. Soehartono Irawan (2011)Metode Penelitian Sosial.Jakarta.Rosda

Drs. M. Dimyati, M.Si(2015) Pedoman Penyusunan Tugas Akhir.Jember.STIE Mandala Jember.

Finch, C R \&. Crunkilton, John R. (1999). Curriculum development in vocational and technical educaton. Needham Heights, MA 02494: Viacom Company.

Ghozali, H. Imam. 2009. Aplikasi Analisis Multivariate dengan Program SPSS. Semarang: Universitas Diponegoro

Ghozali, Imam. (2011). Aplikasi Analisis Multivariate Dengan Program IBM SPSS 19 (edisi kelima.) Semarang: Universitas Diponegoro

Kamus Besar Indonesia, 1989. Balai Pusataka, Jakarta

Muharam, agus (2013). Pengaruh pelaksanaan Praktek Kerja Industri terhadap kesiapan kerja.skripsi.Universitas Pendidikan Indonesia

Nurjannah, Wahyu Tri Iin. 2015. Pengaruh Praktek Kerja Industri Terhadap kesiapan Kerja.Yogjakarta.Universitas Negeri Yogjakarta

Santoso, Singgih (2015) Pengolah Data Statistik Di era Informasi SPSS 20.Jakarta.PT Elex Media Komputindo

Simamora, Henry. 2004. Manajemen Sumber Daya Manusia. STIE YKPN: Yogyakarta

Soenaryo, et al. (2002). Sejarah pendidikan teknik dan kejuruan di Indonesia. Jakarta: Direktorat Pendidikan Menengah Kejuruan.

Sugiyono. 2009. Memahami Penelitian Kualitatif. Bandung: CV. Alfabeta.

Sugiyono. 2010. Metode Penelitian Pendidikan: Pendekatan Kuantitatif, Kualitatif, dan R\&D. Bandung: Alfabeta.

Suparji, Arisandi Avida.2011 Pengaruh praktek kerja industri (prakerin) terhadap kompetensi siswa SMKN 1 Sidoarjo.Skripsi. Universitas Negeri Surabaya

Tim Dosen, Jurusan Adpen. Pengelolaan Pendidikan. Bandung : Jurusan Administrasi endidikan UPI

Timpe, Dale (1993). Kinerja. Jakarta : Gramedia. 
Uno, Hamzah B. (2006). Teori motivasi dan pengukurannya: Analisis di Bidang Pendidikan. Jakarta: Bumi Aksara.

Usman, Moh. Uzwer. (2000). Menjadi guru profesional. Bandung: Remaja Rosdakarya

UU.RI No. 20 Tahun 2003. Sistem Pendidikan Nasional. Jakarta: Asokadikta dan Durat Bahagia.

UU.RI No. 14 Tahun 2004. Tentang Guru dan Dosen. Bandung: Citra Umbara.

UU.RI No. 14 Tahun 2005. Tentang Guru dan Dosen. Fokusmedia.

Winardi. (2001). Motivasi dan Pemotivasian. Jakarta : Raja Grafindo Persada.

Wijaya, Yati. (2007). Kontribusi Kompetensi dan Motivasi Kerja terhadap Kinerja Guru SMPN di Kabupaten Cianjur. Tesis. Program Pascasarjana UPI.

Tidak Diterbitkan. Wirawan. (2001). Evaluasi Kinerja. Jakarta : Erlangga.

Zainun, Buchari. (1989). Manajemen dan Motivasi.Jakarta : Balai Aksara 